\title{
INFUSING GRAPHIC ORGANIZERS AND SHORT STORIES IN LANGUAGE TEACHING
}

\author{
Nuray Alagözlü*
}

\begin{abstract}
$\ddot{O}_{z e t}$
Yapısal bakış açısı içerisinde, kısa öykünün dil öğretiminde etkin bir biçimde ele alınabilmesi için kısa öykülerin anlatı yapıları grafik göstergelerle (graphic organizers) görsel olarak ögrencilere sunulabilir. Bartlett (1932), Propp (1970), Levi-Strauss (1976) temelde anlatı yapısı üzerine araştırmalar yapmışlardır. Rumelhart (1975) bilgiyi öykü sözdizimi şeklinde düzenleyerek, sebeb sonuç ilşkisi üzerinde yoğunlaşmıştır. 1977'de Mandler ve Johnson öykü sözdizimini, öykü unsurları arasındaki iliş̧kileri daha derinlemesine göstermek için dizim ağacı (tree diagram) kullanmıştır. Bu yaklaşım daha sonra Beck ve McKoewn (1981) tarafindan basitleştirilmişstir. Bu çalışmada Thank you Ma'm (Langston Hughes), A Dait's Wait (Ernest Hemingway), and My Father Sits in the Dark (Jerome Wiedman) isimli kısa öykülere ait bazı unsurlar bu yaklaşımı sınıf içinde örneklemek için kullanılacaktır. Bu tür bir yaklaşım yabancı dil öğrencilerinin öyküyü daha iyi anlamalarını sağlayacak ve bilişsel gelişmelerinı arttıracaktır çünkü anlama seviyesinin artması gelişmiş bilişsel ve dilsel becerilerle sıkıca ilişkilidir.
\end{abstract}

Anahtar Sözcükler: Kısa Öykü, Öykünün sözdizimi, Grafik göstergeler

Abstract
Within the structuralist viewpoint, the storymaking elements of the short stories can be visualized after identifying their story grammar, which has implications on language teaching. Bartlett (1932), Propp (1970), Levi-Strauss (1976) originally did research on narrative structure. In 1975, Rumelhart organized the information into story grammar and focused on cause and effect. In 1977, Mandler and Johnson used story grammar in the form of tree diagrams for a more in-depth diagram of relationships between the story elements. This approach was then simplified by Beck and McKoewn in 1981. In this study, the use of graphic organizers on the basis of story grammars of the short stories is demonstrated in American short stories: Thank you Ma'm by Langston Hughes, $\underline{\text { A Dait's }}$ Wait by Ernest Hemingway and My Father Sits in the Dark by Jerome Wiedman. Such an application is believed to help students enhance their understanding and their cognitive development as better comprehension is closely associated with improved thinking and linguistic skills.

Key Words : Story Grammar, Short Story, Graphic Organizers.

* Yrd.Doç.Dr., Başkent Üniversitesi Eğitim Fakültesi İngilizce Öğretmenliği 


\section{1-Introduction}

Recently, literature has been widely integrated in language teaching as it provides meaningful and memorable contexts for processing and interpreting new language. It also transmits cultural knowledge in addition to the fact that it lends itself to linguistic utility. Because language teaching is generally done at the sentence boundary level, students do not have the opportunity to get involved in the literary texts, therefore literary discourse. Keeping in mind that no drills produce a language, using authentic texts in EFL classrooms is of great importance, which will help develop the necessary skills for a better learning.

The problem is generally how to integrate literature in EFL classes. Different genres of literature such as novels, drama, poetry, and short story, might be involved into a language teaching environment in many ways. However, short stories seem to be the unique literary works to make use of due to their practical implementation, compact nature and readibility in one sitting. They are not broad in scope and have a single effect on the readers.

There might be many ways to benefit from the short stories with a maximum effect on the students. Since short stories are neatly organized most of the time (because they are elaborately handled by their writers) and have common elements (story grammars) that lend themselves to an analysis. This analysis can be visualized by graphic organizers which can be manipulated at all stages of teaching reading. Moreover, the use of graphic organizers make the student retrieve the information obtained quite easily, which will support and enhance learning.

In this study, some aspects of American short stories Thank you Ma'm by Langston Hughes, A Dait's Wait by Ernest Hemingway and My Father Sits in the Dark by Jerome Wiedman will be analyzed for classroom application.

\section{2- Story Grammar}

Story" refers to a narrative written discourse. "Grammar" usually is described as the study of words (morphology) and how they come together to form sentences (syntax). However, in reference to "story grammar", "grammar" means "elements". Therefore, "story grammar" addresses the elements of a story. These include but are not limited to: the title, author, setting, main characters, conflict and resolution, events, and conclusion. Some additional elements that may be specified under "events" are: the initiating event, internal response, attempt, consequence, and reaction (Wikidipedia Online).

Story Grammar has a long history with cognitive researchers and narratologists. Led by Bartlett (1932), Propp (1970), Levi-Strauss ( 1976), these researchers sought to find the narrative structure of folk tales, fables, and myths. The information gained by these leading researchers was organized by Rumelhart (1975) in a comprehensive grammar for narrative text. He organized causal relationships that related sentences to each other. Based on Rumelhart's theory, Mandler and Johnson (1977) developed a more flexible story grammar. This story grammar incorporated a tree-like structure to identify the events occurring in a story. Those events include episodes, reactions, paths, goals, attempts, outcomes, 
and an ending reaction. While this model offers a very in-depth study of the events taking place in a story, a more basic story grammar was sought. Beck and McKoewn (1981) simplified Mandel and Johnson's story grammar into a mapping approach. Students identify the main character, the time the story takes place, the location of the story, problems encountered by the characters, the goal of the story, action taken to solve the problem and meet the goal, and the outcome of the story (Marzano, Pickering, Pollock, 2001).

Short story is a work of prose fiction which is shorter than the short novel, more restricted in characters and situations. The structure of a short story is A short story is usually concerned with not more than a few effects, problems or themes. In terms of character development, generally, a single aspect of a character's personality undergoes change or is revealed as a result of some incidents, confrontation or conflict

A short story usually concentrates on a single character involved in a single episode. The turning point in action (climax, the point of highest interest or of highest tension) may occur at the very end. This point may or may not involve denouément (the explanation or resolution of the complications of the story). Many other arrangements are also possible (Abrams, 1993).

Most stories or narrative texts have a predictable structure or pattern of events that create the properties of a story. Erden (2002) presents internal elements of short stories as plot, character, setting, point of view, and theme. The plot is the sequence of events in the story.

In a traditional short story the sequence of events (plot) comprises the following: (Erden, 2002: 29)

\section{A- Plot}

1-Introduction: The characters and setting are described.

2- Conflict: There is usually only one conlict in the short story. The conflict might be man versus nature, (1), man versus society (2), and man versus man (3), man versus himself (4) (Lukens, 1995). The problems main characters are confronted with are presented: internal conflicts, conflicts with other characters.

3- Climax: The part of the story where the excitement is pushed to its limits, especially, at the end of the story).

4-Resolution ( immediately after the climax, the point where the conflict is resolved, but sometimes, the conflict might remain unsolved).

B- Setting is where and when the events take place. The period of history, season or time of the day might be contributory for the interpretation of the theme.

C- Characters. The character(s) is the person (or people) presented by the writer. There are two main types of characters: Protagonist is the hero or heroine, the main character in the story, whom the story centres. Antagonist is the character who opposes the protagonist, the person that helps cause conflict for the protagonist (Smith, 1997).

D-Theme is the central idea of the story which the of the story. The theme is the unifying element of the story; the rest of the literary aspects are organized in a way that supports and defines the theme. The theme can be plainly written, or implied.

E- Point of view is the perspective from which the author tells the story. A narrator might tell the story from 
A first person point of view in which he uses "I" to tell the story and can either be a major or minor participant in the action.

Or he uses a third person point of view in which he uses "he", "she", or "they" to tell the story and does not participate in the action. This narrator can have different levels of information regarding the characters' inner thoughts.

third person omniscient - the narrator uses third person view point, but knows all of the characters' thoughts.

third person limited - third person view point, but the narrator only has access to the thoughts of one or a few of the characters.

objective - this is still the third person view point (uses he, she, or they), but the narrator does not see into the mind of any particular character. The narrator reports action impartially, without telling us what the characters think or feel.

F-Social and Economic Factors which include gender, age, class, race and ethnicity. They influence the way a character behaves and may be the source of conflict in a story.

G- Figures of Speech A short story might contain such elements as

a. Symbolism, a device that evokes more than a literal meaning from a person, object, image or word. When something stands for a concept or idea that is deeper than its original meaning. For example, a rose can be a symbol of love. If the rose is white, the love is pure. If the rose is damaged, the love is damaged (Smith, 1997).

b. Suspense, the excitement and tension that keeps the reader interested in the plot of a narrative. A writer creates suspense by raising questions in the readers mind about what will happen next.

c. surprise ending is a conclusion to a story the reader does not expect.

d. Irony, a device that develops meaning by putting together seemingly contrasting concepts or ideas. Irony occurs when there is a difference between what is asserted or believed, and what is actually the truth. There are many types of irony; below are examples of the most common forms of irony:

- verbal irony - something is said that is the opposite of its intended meaning.

- situational irony - occurs when events turn out opposite than what is expected or desired due to circumstances beyond human control.

- dramatic irony - when the reader or audience knows information that the character does not know, and thereby witnesses the impact of what the character says or does. There is a discrepancy between what the reader knows, and what the character believes to be true. (Smith, 1997).

-

3-Teaching Short Stories through Graphic Organizers: Why to use Graphic Organizers?

As the structure of short stories is appropriate for a representation through graphic organizers which enable readers to see the various elements of a story graphically and explore visually how they work together. Demonstrating the story elements with graphic organizers might initiate a process of meta textual thinking. A graphic organizer is a diagram or illustration of a written or oral statement. Examples include matrices, hierarchies, and continua. The goal in using graphic organizers is to organize ideas and examine relationships. In doing so, people 
engage more of their core thinking skills and process information more intensely, improving long term recall (Drafke, 1993). Facilitating learning, graphic organizers help develop an understanding of a body of knowledge and explore new information and relationships. They are valuable in having students access prior knowledge and gather new knowledge and information.

The elements of a short story, whether it be the attributes of characters, or the elements of setting, or types of conflicts or the causes leading to change in the plot or a character, might be well shown by graphic organizers. As a facilitator, the teacher might choose or adapt among a wide range of graphic organizers, or create his/her own. In the classroom, students might be required to fill in an incomplete story grammar work sheet, which might be a basis for in-class discussion or a writing task. After multiple applications, the students themselves might prepare their own graphic organizers peculiar to the story at hand.

\section{4-Sample classroom applications might be as follows:}

The use of graphic organizers in teaching Thank you Ma'am by Langston Hughes, A Day's Wait by Ernest Hemingway and My Father Sits in the Dark by Jerome Wiedman is displayed below: Graphic Organizers might be selected among a variety of organizers in http://www.enchantedlearning.com/graphicorganizers/

\section{1- A Lotus Chart to visualize the properties of an object/person in "My Father Sits In theDark"}

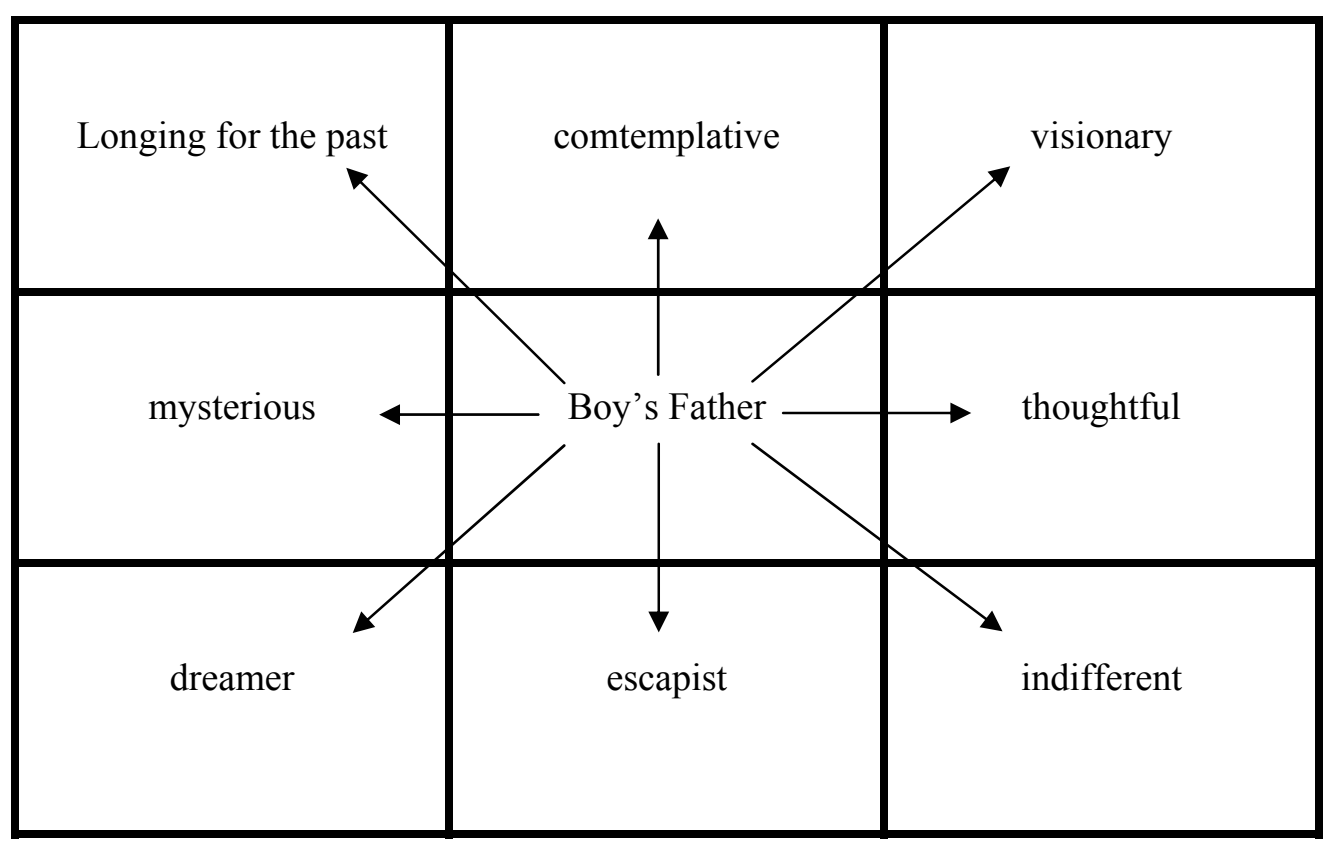


2- Descibing the characters and setting in the story.

Title: Thank you Ma'am by Langston Hughes

\begin{tabular}{|c||}
\hline Characters: \\
Mrs. Luella Bates Washington \\
Jones \\
Roger \\
\\
\hline
\end{tabular}
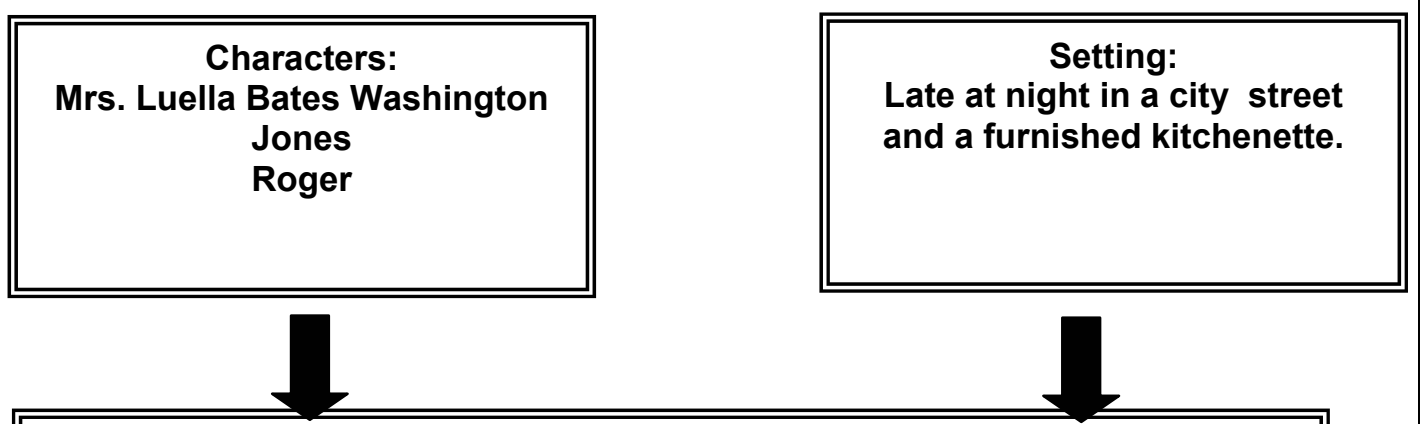

Problem/Conflict:

MAN VERSUS MAN- Mrs. Bates is in conflict with Roger

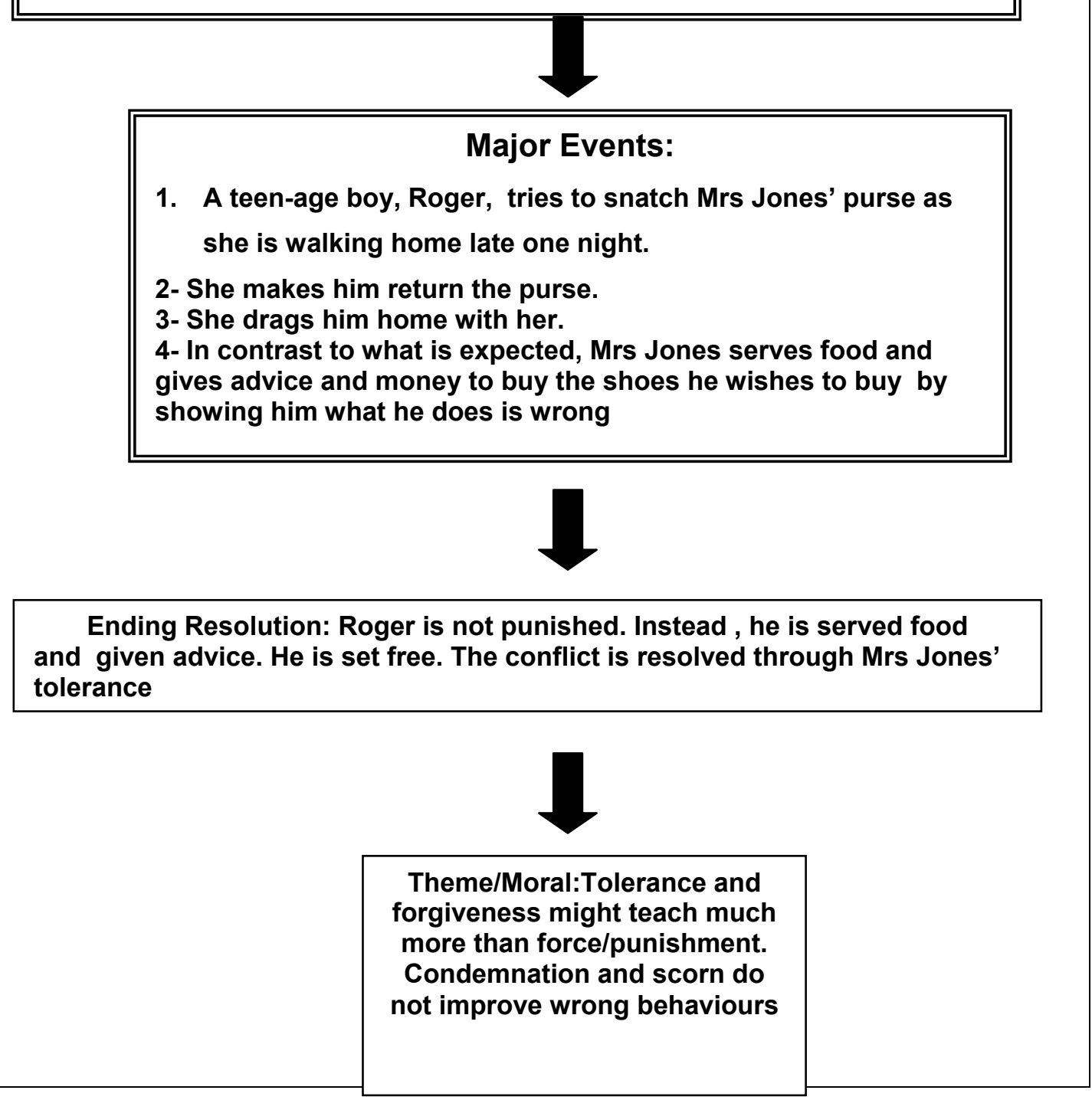


3- Storyline (plot) in the story A Day's Wait.

\section{Problem or Story Title: A Day's Wait}

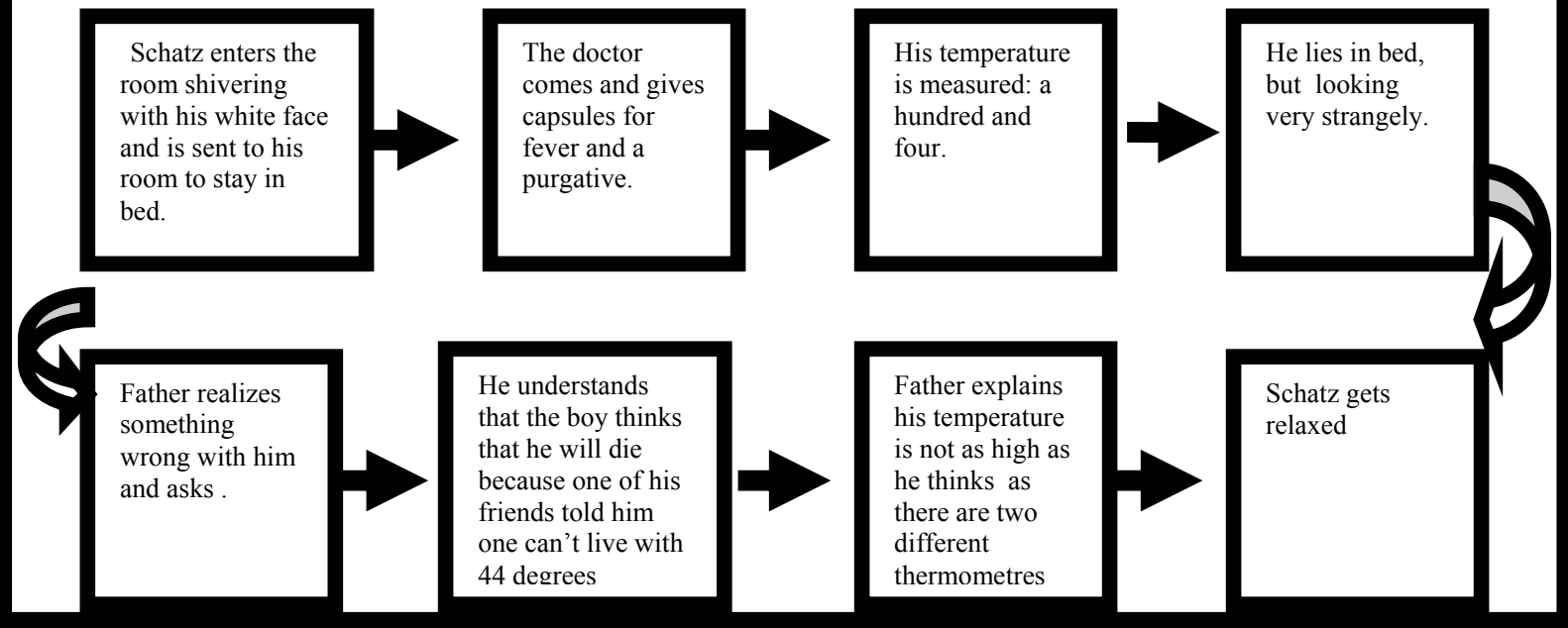

4-

Characters in "Thank you Ma'am"

\section{ROGER}

Timid, shy, uneducated, misguided, alone in life hopeless, scared, apologetic
Mrs JONES

Helpful, emphatizing tolerant, dignified

4- Cause and Effect Pattern: An Outline of the causes that make the boy steal in "Thank you Ma'm.

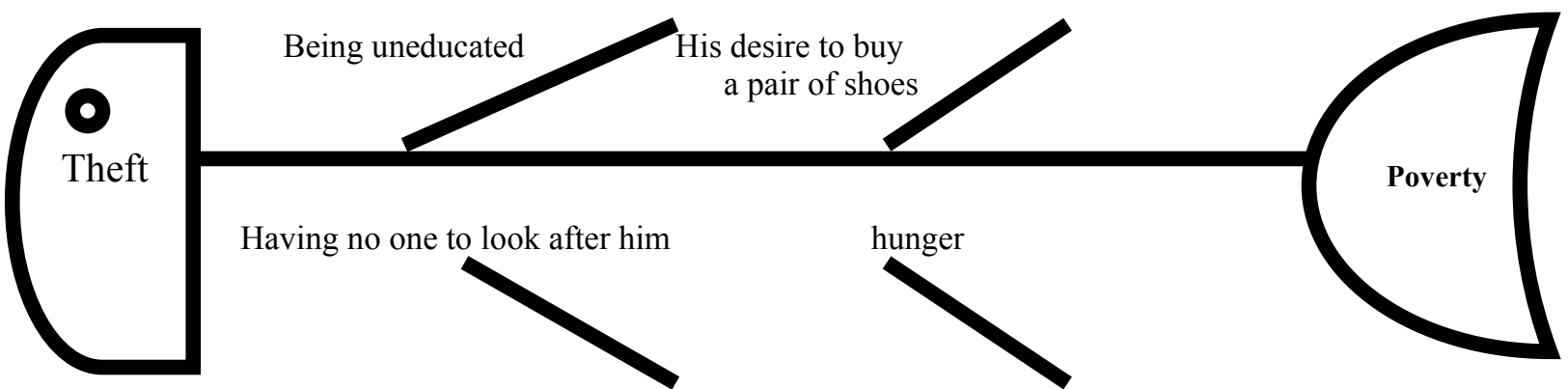


Note: Causes are shown by the ribs of the fishbone and the effect is the head of the fish . Poverty is the root cause for theft.

\section{Conclusion}

All sorts of literary texts (short stories, novels, drama, poetry) are of value in teaching a foreign language. Especially short stories, more compact and condensed, are practical for classroom use. The story making elements in a short story like plot, characters, conflict, climax, and resolution can be easily recognized and demonstrated by graphic organizers, which are effective visual aids that arrange essential aspects of an idea or topic into a pattern using labels.

Teaching short stories via graphic organizers immerses students into thinking as literary texts are argumentative in nature. As each detail (facts, relationships, properties, conflict, storyline(plot), characters) can be easily visualized through the use of graphic organizers, graphic organizers are worthy to promote thinking skills to a great extent (Grabe, 1997:2-15). Graphic organizers help students recall the information in the text to be used for claims, arguments, evidence, reasons, and assumptions on which they will probably construct their reasoning and which give way to healthy reasoning, evaluations, and decisions.

The use of graphic organizers in teaching short stories might be effectively used especially at post reading stage, after the story is read once and comprehended, as they are valuable in initiating thinking to solve story-based problems and to make decisions. Therefore, the bond between reading and thinking can be strenghtened through graphic organizers as they also foster critical thinking necessary at all levels of education for individuals who are aware of their own learning. Students learn thinking rather than "parroting".

\section{References}

Abrams, M.H. ( 1993) A Glossary of Literary terms. Harcourt Brace College Publishers.

Akyol, H. Hikaye haritası Yöntemiyle Metin Öğretimi. Online: http://yayim.meb.gov.tr/dergiler/medergi/15.htm

Bartlett , F.C. ) Remembering Cambridge England University Pres 1932317 p

Beck, I. L., \& McKoewn, G. M. (1981). Developing questions that promote comprehension: The story map. Language Arts, 58, 913-918.

Drafke, M. (1993). Graphic Organizers. http://www.cod.edu/people/faculty/drafke/Graphic\%20organizers.htm\#Graphic\%2 0Organizers $\% 20 \mathrm{In} \% 20 \mathrm{General}$

Erden, A Kısa Öykü ve Dilbilimsel Eleştiri (Istanbul: Gendaş Yayınları, 2002)

Grabe, B. (1997) Discourse Analysis and Reading Instruction. In Functional Approaches to Written Text: Classroom Applications (2-15) English Language Programs United States Information Agency.

Marzano, R., Pickering, D.J., \& Pollock, J.E. (2001). Classroom instruction that works: Research-based strategies for increasing student achievement. Alexandria, VA: ASCD.

Levi-Strauss, C. (1967). "The Structural Study of Myth," Structural Anthropology. Garden City, N.Y.: Anchor Books.

Mandler. J. M. (1978) A code in the node: the use of a short schema in retrieval . Discourse Process. P. 14-35 
Propp, V. (1970). Morphologie du Conte. Seuille, Paris. Masalın Biçimbilimi (translated by M. Rifat, S. Rifat). BFS Yayınları İstanbul.

Rumelhart D.E. (1980) Notes on a Schema for Stories. Bobrow D.G. \& Collins A. Eds.) Representation and understanding studies in cognitive science. New York Academic press 211-36

Smith, V. (1997) Guide to Fiction. Online: http://depts.gallaudet.edu/Englishworks/

Hughes, L. (1998) Thank You Ma'm in America Writes (eds. Kay, J and R.M. Gelshenen).

Hemingway, E. (1998) A Day's Wait. in America Writes (eds. Kay, J and R.M. Gelshenen).

Wiedman, J. (1998). My Father Sits in the Dark in America Writes (eds. Kay, $\mathrm{J}$ and R.M. Gelshenen).

Wikidipedia- Online Encyclopedia. Online: http://wik.ed.uiuc.edu/index.php/Story_grammar 